\title{
Red-Pigmented Micrococci: a Basis for Taxonomy
}

\author{
B. W. BROOKS, ${ }^{\prime} \dagger$ R. G. E. MURRAY, J. L. JOHNSON, ${ }^{2} \ddagger$ E. STACKEBRANDT, ${ }^{3}$ \\ C. R. WOESE, ${ }^{3}$ AND G. E. FOX ${ }^{4}$
}

Department of Microbiology and Immunology, University of Western Ontario, London, Ontario, Canada N6A 5C1; Anaerobe Laboratory, Virginia Polytechnic Institute, Blacksburg, Virginia $24061 ;^{2}$ Department of Genetics and Development, University of Illinois, Urbana, Illinois $61801{ }^{3}$ and Department of Biophysical Sciences, University of Houston, Houston, Texas $77004^{4}$

Fifty strains of red-pigmented, gram-positive, nonfermentative micrococci were studied, including organisms from diverse collections identified as Micrococcus roseus, M. agilis, "Sarcina erythromyxa," "M. radiodurans," "M. radiophilus," and " $M$. radioproteolyticus" and miscellaneous unidentified strains usually labelled $M$. roseus (names in quotation marks are not on the Approved Lists of Bacterial Names, Int. J. Syst. Bacteriol. 30:225-420, 1980). Although similar in physiological attributes (negative characters predominated), the cell wall structural profiles separated $M$. roseus and $M$. agilis (simple homogeneous profile) from " $M$. radiodurans" and the radiation-resistant group (complex, multilayered profile). Simple reactions (growth in $5 \% \mathrm{NaCl}$ broth, growth at $37^{\circ} \mathrm{C}$, and nitrate reduction) distinguished $M$. roseus from $M$. agilis, and acid production from glucose and other sugars distinguished " $M$. radioproteolyticus" from the rest. The members of the " $M$. radiodurans" group could be typified by physiological reactions but not with great reliability. Gas-liquid chromatography of extracted lipids showed that veritable $M$. roseus and $M$. agilis strains had at least $50 \%$ of fatty acids in the form of 15:0 branched chains. " $M$. radiodurans" and the rest had straight chains with a 16:1 component which formed at least $25 \%$ of total fatty acids and which was not possessed by $M$. roseus or $M$. agilis. Further studies were based on representative strains of clusters derived from the abovementioned tests. Zymograms for nonspecific esterases and chromatograms of extracted pigments showed no identical patterns for any 2 of 10 strains. Absorption spectra for pigments had maxima at 450 to $510 \mathrm{~nm}$. The guanine plus cytosine contents of the deoxyribonucleic acids ranged from 62 to $74 \mathrm{~mol} \%$ : the $M$. roseus$M$. agilis cluster was $>69 \mathrm{~mol} \%$, and the radiation-resistant cluster was $<71 \mathrm{~mol} \%$. There was little deoxyribonucleic acid homology between $M$. roseus and $M$. agilis $(8 \%)$ or among any of the rest $(<21 \%)$. The named radiation-resistant species showed $<18 \%$ homology to each other, but alignments were detected in the miscellaneous group. Ribosomal ribonucleic acid (16S) cataloguing showed that " $M$. radiodurans," " $M$. radiophilus," and one of the miscellaneous radiationresistant strains were related $\left(S_{A B}=0.51\right.$ to 0.63$)$ but that they had as little oligonucleotide similarity to $M$. luteus and $M$. roseus $\left(S_{A B}=0.23\right)$ as they all did to Escherichia coli. It is concluded that " $M$. radiodurans" and its relatives are not species of Micrococcus and that they represent clones that separated from the main stem early in procaryotic evolution. There are at least five such species: "M. radiodurans," "M. radiophilus," "M. radioproteolyticus," "M. erythromyxa" (Sarcina erythromyxa), and one other unnamed.

The genus Micrococcus Cohn 1872, as outlined by Baird-Parker (3), consists of three species: Micrococcus luteus (Schroeter) Cohn 1872, $M$. varians Migula 1900; and $M$. roseus Flügge 1886. This represents not only a reduction in the number of species from 16 in the seventh edition

$\dagger$ Present address: Department of Veterinary Microbiology and Immunology, University of Guelph, Guelph, Ontario, Canada.

$\ddagger$ Present address: Institut für Botanik und Mikrobiologie, Technische Universität, 8 Munich 2, West Germany. of Bergey's Manual (1957) but also the inclusion of red-pigmented strains previously in the genus Sarcina Goodsir 1842 (e.g., Sarcina rosea).

The red-pigmented Micrococcus strains are of particular interest because a number of them are known to be extremely radiation resistant, notably " $M$. radiodurans" (1). (Names in quotation marks are not on the Approved Lists of Bacterial Names [43].) Due to their limited action on substrates, these organisms were assumed by Hill (15) to form a natural group. This 
was a hazardous assumption because the similarity between strains was based upon negative characters. Some of the strains possess distinctive features indicative of inhomogeneity. One strain, previously identified as a member of $M$. agilis Ali-Cohen 1889, was originally described as having swimming motility. Recent studies of radiation-resistant strains have shown that the cell wall of these organisms has extraordinary structural features $(25,44,50,55)$; other radiation-resistant organisms seem to have unusually thick walls (38). Baird-Parker (3) included the radiation-resistant micrococci in one species incertae sedis, " $M$. radiodurans" (35), and thus maintained the alliance with the genus Micrococcus. Stackebrandt and Woese (47) included " $M$. radiodurans" in their survey of ribonucleic acid (RNA) sequences in the Micrococcaceae and concluded that it was distinct from other species in the genus and bore no detectable specific relationship to gram-positive bacteria in general.

Interest in resolving the problems concerning the classification of the red-pigmented micrococci was stimulated by the isolation of other radiation-resistant, red-pigmented micrococci $(10,23,27)$. Reports in the literature $(14,27,44$, $45,50,55)$ suggest that these organisms are not closely related to the typical gram-positive micrococci and that they should be reclassified because of their unusual cell wall structure and composition. There is insufficient information for a thorough comparison. Some of the isolates have been described as new species: " $M$. radiophilus" (27) and " $M$. radioproteolyticus" $(23)$.

We have studied 50 strains of red-pigmented, gram-positive, catalase-positive cocci from worldwide sources with the objective of identifying and assessing characters that would allow clustering and a more effective approach to classification and taxonomy.

(This paper is derived in part from an M.Sc. thesis by B. W. Brooks, University of Western Ontario, Ontario, Canada, 1978.)

\section{MATERIALS AND METHODS}

Bacterial strains. The strains used in this study and their sources are given in Table 1. Stock cultures were maintained on the tryptone-glucose-yeast extract-methionine (TGYM) medium of Work and Griffiths (55) with the addition of $1.5 \%$ (wt/vol) agar; incubation was at $30^{\circ} \mathrm{C}$.

Growth of bacteria in batch cultures. The inoculum for batch cultures was obtained from $20 \mathrm{ml}$ of TGYM broth in a 125-ml Erlenmeyer flask inoculated from the appropriate stock culture and shaken (120 $\mathrm{rpm})$ at $30^{\circ} \mathrm{C}$ for 18 to $48 \mathrm{~h}$ in a reciprocating water bath shaker (New Brunswick Scientific Co., New Brunswick, N.J.). Some strains grew slowly and re- quired more than $18 \mathrm{~h}$ to attain noticeable turbidity. Baffled culture flasks (2 liter, Bellco Glass, Inc., Vineland, N.J.) containing 1 liter of TGYM were inoculated with $5 \mathrm{ml}$ of the above-mentioned culture and were shaken (Gyrotary shaker, New Brunswick Scientific Co.) at $30^{\circ} \mathrm{C}$ and $120 \mathrm{rpm}$. Growth was monitored by measuring turbidity with a Klett-Summerson photoelectric colorimeter (Klett Manufacturing Co., Inc., New York, N.Y.).

Determination of fatty acid composition by gas-liquid chromatography. Cells from batch cultures were harvested during the exponential phase of growth by centrifugation at $4,000 \times g$ for $15 \mathrm{~min}$ in a Sorvall superspeed centrifuge (Ivan Sorvall, Inc., Norwalk, Conn.), washed twice in $50 \mathrm{ml}$ of $0.9 \%$ (wt/vol) sodium chloride, resuspended in $10 \mathrm{ml}$ of $0.9 \%$ (wt/ vol) sodium chloride, and freeze-dried. The methods used for extraction of the lipids and transmethylation were those of Tadayon et al. (49). Fatty acid methyl esters were analyzed by gas-liquid chromatography on a 10-ft, 1/8-in. $(3 \mathrm{~m}, 3.2 \mathrm{~mm})$ stainless-steel polar column of $10 \%$ SP-2330 on 100/200 Chromosorb (Supelco, Inc., Bellefonte, $\mathrm{Pa}$.) in a Beckman GC-65 chromatograph with hydrogen flame detector. The column was operated at $190^{\circ} \mathrm{C}$ (detector temperature, $260^{\circ} \mathrm{C}$ ) with nitrogen used as the carrier gas. Identification of fatty acids was based on comparison of retention times with those of methyl ester standards (Supelco, Inc., and Applied Science Laboratories, State College, Pa.). Relative percentages of individual fatty acid components were determined from gas-liquid chromatography tracings (6).

Electron microscopy of thin sections. For ultrathin sectioning, log-phase cells, grown in TGYM and incubated at $30^{\circ} \mathrm{C}$, were fixed by the procedure of Ryter and Kellenberger (37). Two modifications of this procedure that were used with a few strains involved: (i) prefixation with $10 \%$ (wt/vol) saturated picric acid and (ii) postfixation with $10 \%$ saturated picric acid added to $1 \% \mathrm{OsO}_{4}$ in Veronal-acetate buffer immediately before use. Dehydration was carried out in increasing concentrations of ethanol. Blocks were embedded in Epon 812 (Ladd Research Industries, Burlington, Vt.) and cured for $72 \mathrm{~h}$ at $60^{\circ} \mathrm{C}$. Sections were stained by floating grids carrying sections on $2 \%$ (wt/vol) uranyl acetate and, in some cases, were further stained with lead citrate by the method of Reynolds (36). Thin sections were examined with a Philips EM-200 electron microscope operating at $60 \mathrm{kV}$. Micrographs were taken on 35-mm Kodak Fine Grainpositive film.

Metabolic and physiological testing. Catalase production, nitrate reduction, and the presence of $\beta$ galactosidase ( $o$-nitrophenyl- $\beta$-D-galactopyranoside test) were determined by the methods described by MacFaddin (28). The procedure of Sneath (46) was used to determine the ability of an organism to hydrolyze esculin. TGYM agar was used to determine growth at 30 and $37^{\circ} \mathrm{C}$. Salt tolerance was observed on TGYM agar with $5 \%(\mathrm{wt} / \mathrm{vol})$ sodium chloride. Two different basal media were used for fermentation tests: (i) the standard medium adopted by the International Committee on Systematic Bacteriology Subcommittee on the Taxonomy of Staphylococci and 
Micrococci (48) and (ii) a peptone-water base which contained proteose peptone $3(1 \%$, wt/vol; Difco) sodium chloride $(0.5 \%$, wt/vol), bromocresol purple $(0.004 \%$, wt $/ \mathrm{vol})$, and the appropriate carbohydrate $(1 \%$, wt $/$ vol $)$. Tubes were inoculated and incubated aerobically at $30^{\circ} \mathrm{C}$ for up to 3 weeks.

Comparative zone electrophoresis of esterases. Staphylococcus aureus PM261 (obtained from W. E. Kloos, Genetics Department, North Carolina State University, Raleigh, NC 27607) was used as a reference strain. The methods of Zimmerman and Kloos (57) were used. Vertical gel electrophoresis was performed on a GE-4 gel electrophoresis apparatus (Pharmacia Fine Chemicals, Inc., Piscataway, N.J.).

Pigment analysis. Cells from batch culture were harvested during the exponential phase of growth by centrifugation at $4,000 \times g$ for $15 \mathrm{~min}$ at $4^{\circ} \mathrm{C}$, washed twice in $0.9 \%$ (wt/vol) sodium chloride, resuspended in $0.9 \%$ (wt/vol) sodium chloride, frozen, and stored at $-20^{\circ} \mathrm{C}$. Cell suspensions were brought to room temperature, and the cells were pelleted by centrifugation at $5,000 \times g$ for $15 \mathrm{~min}$ at $4^{\circ} \mathrm{C}$. The wet pellet was extracted by the two-phase method of Bligh and Dyer (4). Light was excluded, and access of oxygen was minimized as much as possible throughout the entire procedure by displacement with nitrogen gas. The combined chloroform phases were evaporated to dryness, resuspended in benzene, and stored at $-20^{\circ} \mathrm{C}$ under nitrogen and in the dark. Thin-layer chromatography was carried out with the use of glass plates with $0.25-\mathrm{mm}$ thick layers of silica gel $\mathrm{H}$ (Merck $\mathrm{AG}$, Darmstadt, Germany; 1 part silica gel $\mathrm{H}$ to 5 parts distilled water). Immediately before use, plates were activated by heating at $120^{\circ} \mathrm{C}$ for $1 \mathrm{~h}$. The solvent system was a mixture of petroleum ether-acetonechloroform (25:25:20, vol/vol [9]). $\beta$-Carotene (Sigma Chemical Co., St. Louis, Mo.) was included as a standard with each run. Absorption spectra (250 to 600 $\mathrm{nm}$ ) were determined for extracted segments with a Unicam SP1700 UV spectrophotometer.

Peptidoglycan typing. The peptidoglycan composition of the representative strains was determined by the methods used by Schleifer and Kandler (41) in comparing the structure of this polymer from a wide range of bacteria. The isomeric configurations of amino acids were not determined.

DNA isolation. The cells were suspended in 0.15 $\mathrm{NaCl}-0.01 \mathrm{M}$ ethylenediaminetetraacetic acid buffer, pH $8.0(29)$. Lysozyme $(100 \mu \mathrm{g} / \mathrm{ml})$ was added, and the suspension was incubated at $37^{\circ} \mathrm{C}$ for 0.5 to $1.0 \mathrm{~h}$ to make the cells susceptible to lysis with $1 \%$ sodium dodecyl sulfate. The deoxyribonucleic acid (DNA) from most of the lysates was isolated by a hydroxylapatite procedure (19). High-molecular-weight DNA was used for in vitro labeling. After an initial extraction with chromatography-grade phenol, high-molecularweight DNA was isolated by the Marmur procedure (29).

G+C content of DNA. The guanine plus cytosine $(\mathrm{G}+\mathrm{C})$ contents of DNA preparations were calculated by using the thermal melting points $\left(T_{m}\right)$ of the DNA preparations $(20,30)$.

Preparation of labeled DNA. High-molecularweight DNA $(200 \mu \mathrm{g} / \mathrm{ml})$ was nicked by incubating it with $0.1 \mu \mathrm{g}$ of deoxyribonuclease I (electrophoretically purified) per $\mathrm{ml}$ for $1 \mathrm{~min}$. The DNA $(10 \mu \mathrm{g})$ was then labeled with $\left[{ }^{3} \mathrm{H}\right]$ thymidine triphosphate by a nick translation method (7). The specific activity of the labeled DNA preparations was about $100,000 \mathrm{cpm} / \mu \mathrm{g}$.

DNA homology experiments. A variation of the S1 nuclease procedure described by Crosa et al. $(8,18$, 21) was used in DNA homology experiments. The reassociation mixtures contained $10 \mu \mathrm{l}(0.025 \mu \mathrm{g})$ of labeled DNA, $50 \mu \mathrm{l}(30 \mu \mathrm{g})$ of unlabeled DNA (either homologous, heterologous bacterial DNA or native fragmented salmon sperm DNA), and $50 \mu$ l of $0.88 \mathrm{M}$ $\mathrm{NaCl}+0.001 \mathrm{M}$ HEPES ( $N$-2-hydroxyethylpiperazine- $N^{\prime}$-2-ethanesulfonic acid) buffer (pH 7.0). Just prior to each experiment, the amount of labeled DNA needed for the experiment was denatured by heating the tube in a boiling-water bath for $5 \mathrm{~min}$. Reaction vials containing native salmon sperm DNA were used to measure the amount of self-renaturation of labeled DNA during the incubation period. The reaction vials were incubated for $17 \mathrm{~h}$ at $70^{\circ} \mathrm{C}$.

After incubation, a $100-\mu$ l sample was removed from each vial and transferred into a tube (13 by $100 \mathrm{~mm}$ ) for $\mathrm{S} 1$ nuclease digestion. In addition to the sample of reassociation mixture, each digestion tube contained $1.0 \mathrm{ml}$ of the $25 \mu \mathrm{g}$ of fragmented, denatured salmon sperm DNA and $50 \mu$ l of S1 nuclease (CalbiochemBehring). The preparation was diluted such that twice the amount of enzyme was added that was needed to digest totally $25 \mu \mathrm{g}$ of denatured DNA in $1 \mathrm{hr}$ (21). After incubation for $1 \mathrm{~h}$ at $50^{\circ} \mathrm{C}$, an equal volume of $10 \%$ trichloroacetic acid was added to each tube. After cooling in a refrigerator for at least $1 \mathrm{~h}$, the precipitates were collected on nitrocellulose filters (BA 85, Schleicher \& Schuell Co., Keene, N.H.). The membranes were dried, and the radioactivity was measured by use of liquid scintillation counter and a toluenebase scintillation fluid.

Comparative cataloging of $16 \mathrm{~S}$ ribosomal RNA. A limited set of organisms (" $M$. radiodurans" Sark 298, " $M$. radiophilus" $1055, M$. roseus 294 , and $M$. roseus 1057 ) were compared by cataloging the $T_{1}$ ribonuclease digests of the $16 \mathrm{~S}$ ribosomal RNA from each strain. This ubiquitous and essential macromolecule provides evidence of sequences showing extreme conservation as well as variable regions appropriate to a semantide useful for estimation of both distant and close relationships (53). The labeling $\left({ }^{32} \mathrm{P}\right)$, extraction, purification, digestion, electrophoretic separation, and analysis of the resulting oligonucleotide "fingerprint" have been systematized and have been published in detail $(40,51,54)$. The oligonucleotide catalogs were subjected to a computer-assisted comparison, and an association coefficient, $S_{A B}$, was generated according to the derivation given by Fox et al. (13); all oligomers of length six and longer, the post-transcriptionally modified oligomers, and the $3^{\prime}$ and $5^{\prime}$ termini were used as the data base.

\section{RESULTS}

Metabolic and physiological characters. All strains were gram positive and catalase positive. The majority of the metabolic and physiological tests, including methyl red, Voges-Pros- 


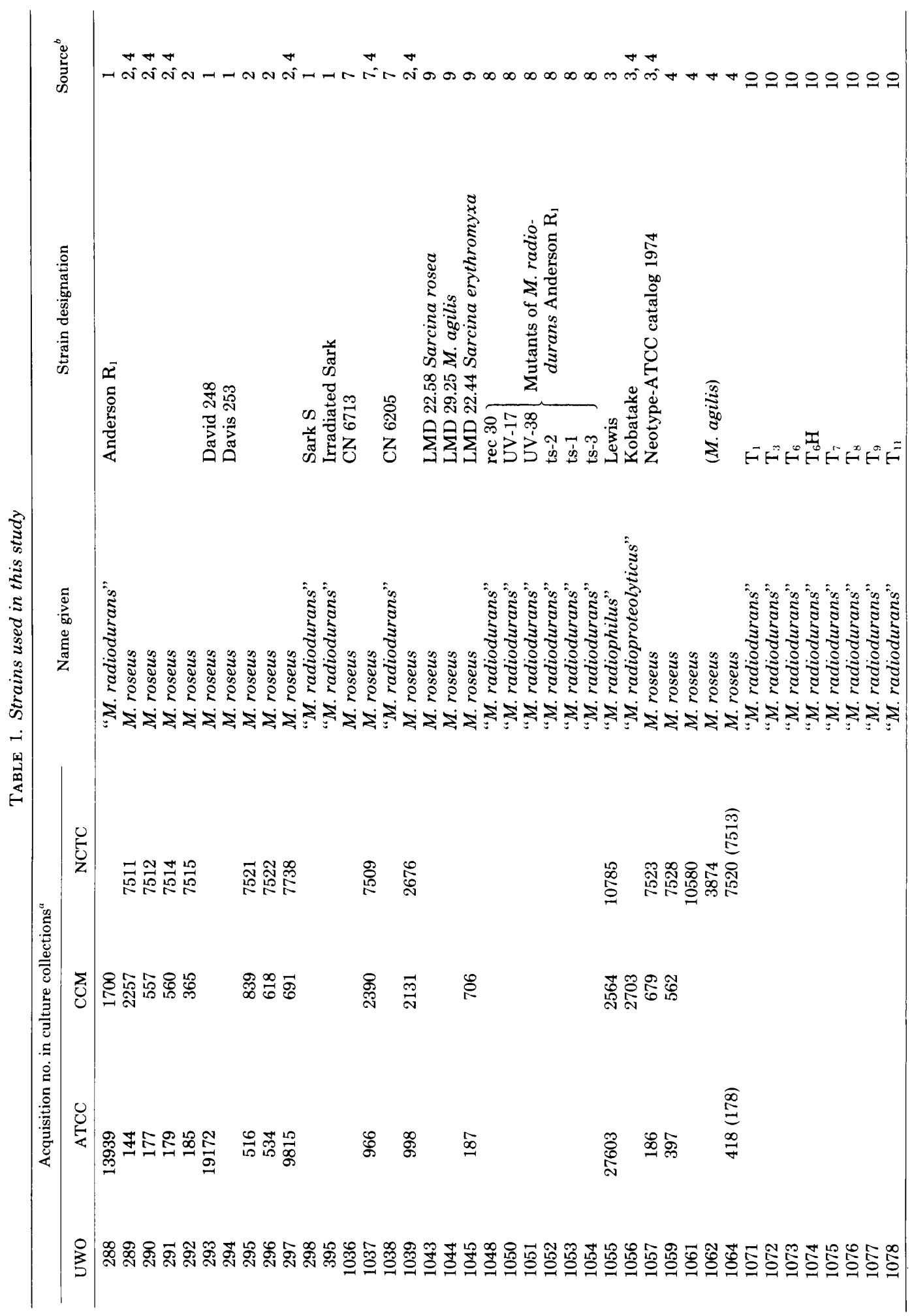




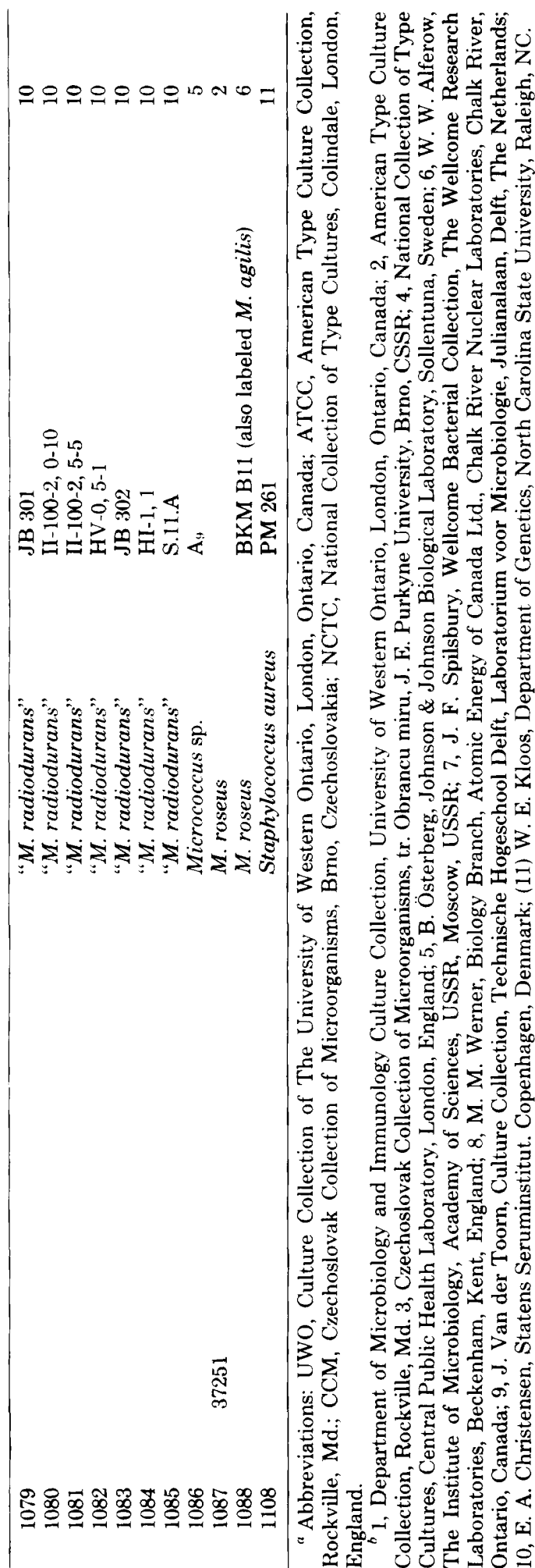

kauer, indole, and citrate tests, gave negative results. No acid production was detected for any of the 52 strains using the following carbohydrates as substrates: arabinose, mannitol, sucrose, lactose, maltose, galactose, xylose, or sorbitol. However, some tests distinguished strains, and the results are depicted in Table 2.

Most strains of $M$. roseus listed in Table 2 grew at $37^{\circ} \mathrm{C}$, grew in the presence of $5 \%$ sodium chloride, and reduced nitrate to nitrite. Strains included in this study and formerly recognized as members of $M$. agilis ( $M$. roseus UWO 1037, 1039,1044 , and 1062) were distinct in that they all failed to grow at $37^{\circ} \mathrm{C}$, failed to grow in the presence of $5 \%$ sodium chloride, and were unable to reduce nitrate. Similar results were obtained by Kocur and Schleifer (24) with five strains of M. agilis.

Cell wall profiles. Sections of the type strain (UWO 1057) of $M$. roseus showed a single, homogeneous, thick component ( 40 to $45 \mathrm{~nm}$ ) external to the plasma membrane (Fig. 1) consistent with the wall profiles of gram-positive bacteria such as Staphylococcus aureus and $B a$ cillus licheniformis (31). This type of profile was consistent for all strains identifiable with $M$. roseus Flügge and $M$. agilis Ali-Cohen. All others in the series had a multilayered profile (Fig. $2-7$ ), including the organism formerly named " $S$. erythromyxa" (Fig. 2).

The " $M$. radiodurans" strains showed the most complex profile $(25,55)$, including, from inside to outside: a compartmentalized layer, a delicate unit membrane, and an outermost hexogonal array of macromolecules. The inner dense layers (peptidoglycan containing, 10 to 20 nm thick) of " $M$. radiodurans" UWO 288,298 , 1083 , and 1085 and of $M$. roseus UWO 293 and 294 showed regular fenestrations, described in earlier papers (see 25) as the "holey layer." These fenestrations were not seen in " $S$. erythromyxa," " $M$. radiophilus," or " $M$. radioproteolyticus." The complexity of the profile and a fenestrated or nonfenestrated peptidoglycan layer provided the most useful characters.

Fatty acid composition. The fatty acid composition of the organisms included in this study was determined by gas-liquid chromatography. The strains were then sorted (Tables 3,4 , and 5 ) on the basis of predominant fatty acid components.

The major fatty acid component of the strains with similar patterns assembled in Table 3, clustered around the type strain of $M$. roseus, was a methyl-branched C15 saturated acid. The retention time of this peak corresponded exactly with that of a C15:0 anteiso standard and indicated 


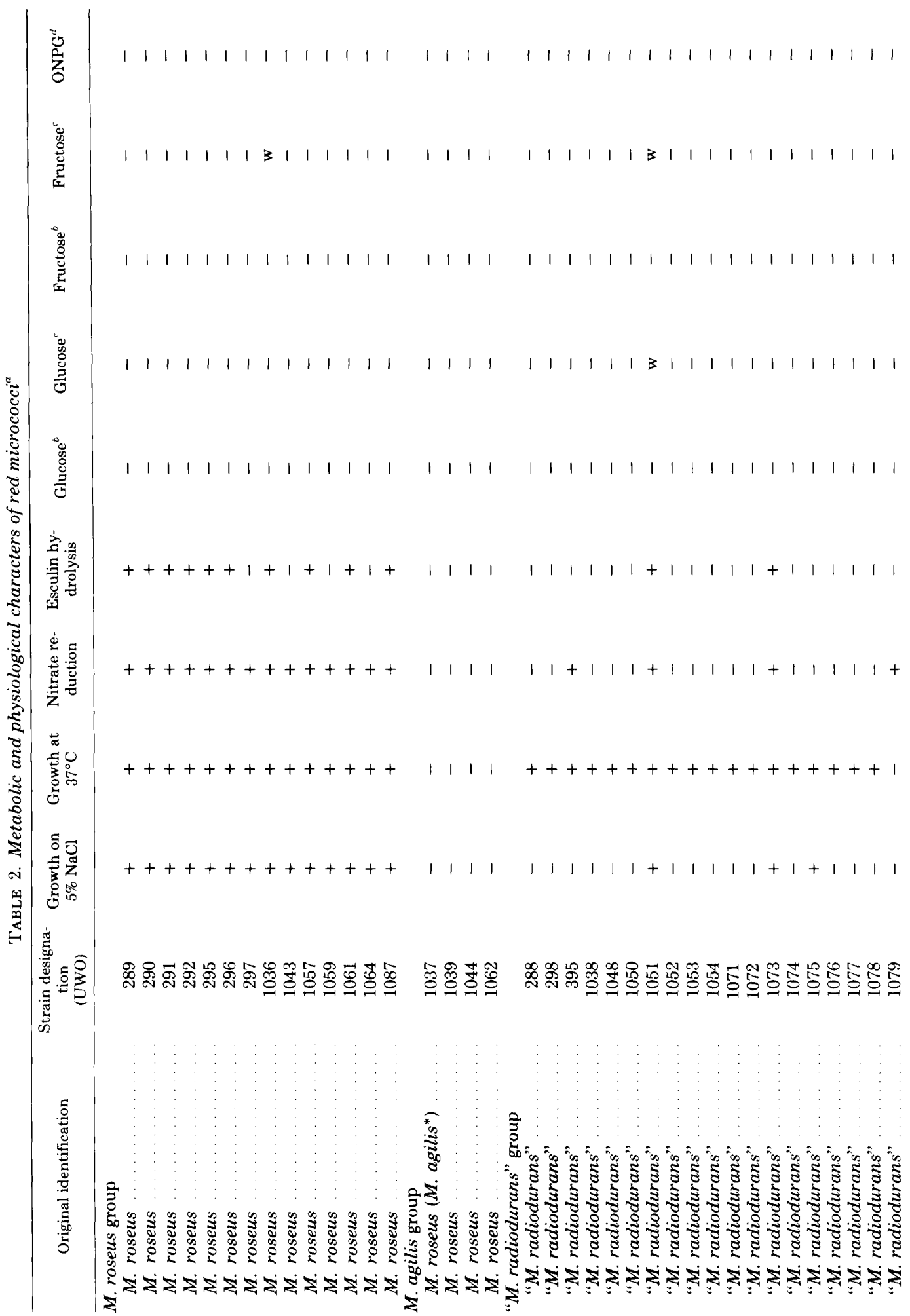




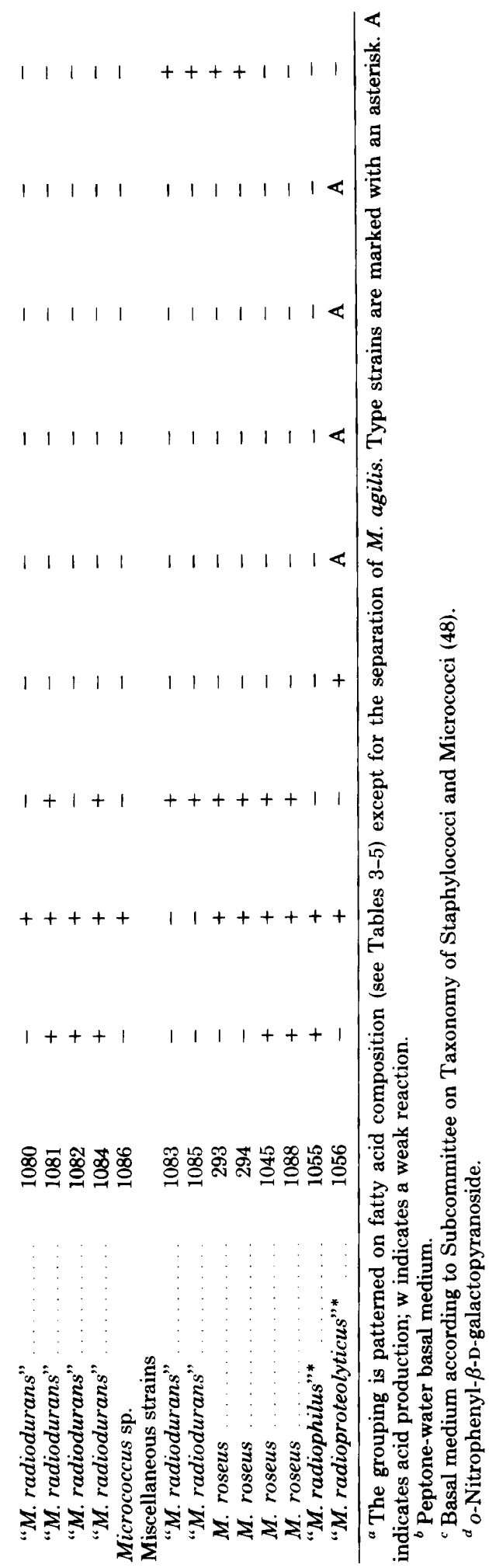

a high concentration. However, the broad base of this peak made it impossible to determine whether or not a very minor C15:0 iso component was present, and, therefore, the notation C15:0 $\mathrm{Br}$ was used. The relative percentage of the $\mathrm{C} 15: 0 \mathrm{Br}$ component varied between strains, and in most cases this difference was made up mainly by a higher proportion of the $16: 0 \mathrm{com}$ ponent. The proportions of the component fatty acids correspond with those in the more limited study of Jantzen et al. (17), except for our finding of relatively more of the $16 \mathrm{C}$ chains. The proportion of the fatty acids varied among closely related strains. The relative proportions of the C15:0 Br component of $M$. roseus UWO 1039 and UWO 1062, previously identified as $M$. agilis, were similar. However, the relative proportions of some of the minor components of these two strains were different.

In Table 4 are assembled the strains which had a predominant 16:1 fatty acid component. No branched-chain fatty acids were detected in any of these strains. A comparison of the fatty acid composition of " $M$. radiodurans" UWO 288 , and the derivatives of this strain obtained by Moseley-UWO 1048 (33), UWO 1050 and UWO 1051 (32), and UWO 1052, 1053, and 1054 (34)-indicated no qualitative differences in the types of fatty acids present but some variations in the relative proportions.

Strains assembled in Table 5 have fatty acid patterns unlike those of strains in Tables 3 and 4. Although the fatty acid patterns of " $M$. radiophilus" and "M. radioproteolyticus" were similar to those in Table 4 (16:1 predominant), no branched-chain fatty acids were detected. However, some novel components not identified by the system used were detected in " $M$. radiophilus," and a 19:1 component was detected in " $M$. radioproteolyticus" extracts. The remaining six strains sorted into three groups (see Table 5).

Selection of representative strains. Cell wall profiles, fatty acid composition, and the results of metabolic and physiological tests provided differential characters which allowed clustering of similar strains. Further testing was carried out only on representative strains from each cluster, as follows: $M$. roseus and $M$. agilis strains listed in Tables 2 and 3; " $M$. radiodurans" strains listed in Tables 2 and 4 (UWO 288 and 298); and from Table 5 " $M$. radiodurans" strains UWO 1083 and $1085, M$. roseus strains UWO 293 and 294, $M$. roseus strains UWO 1045 and 1088 , "M. radiophilus" UWO 1055, and " $M$. radioproteolyticus" UWO 1056.

Comparative zone electrophoresis of nonspecific esterases of representative strains. Figure 8 depicts the relative mobilities of the nonspecific esterases on polyacrylamide 

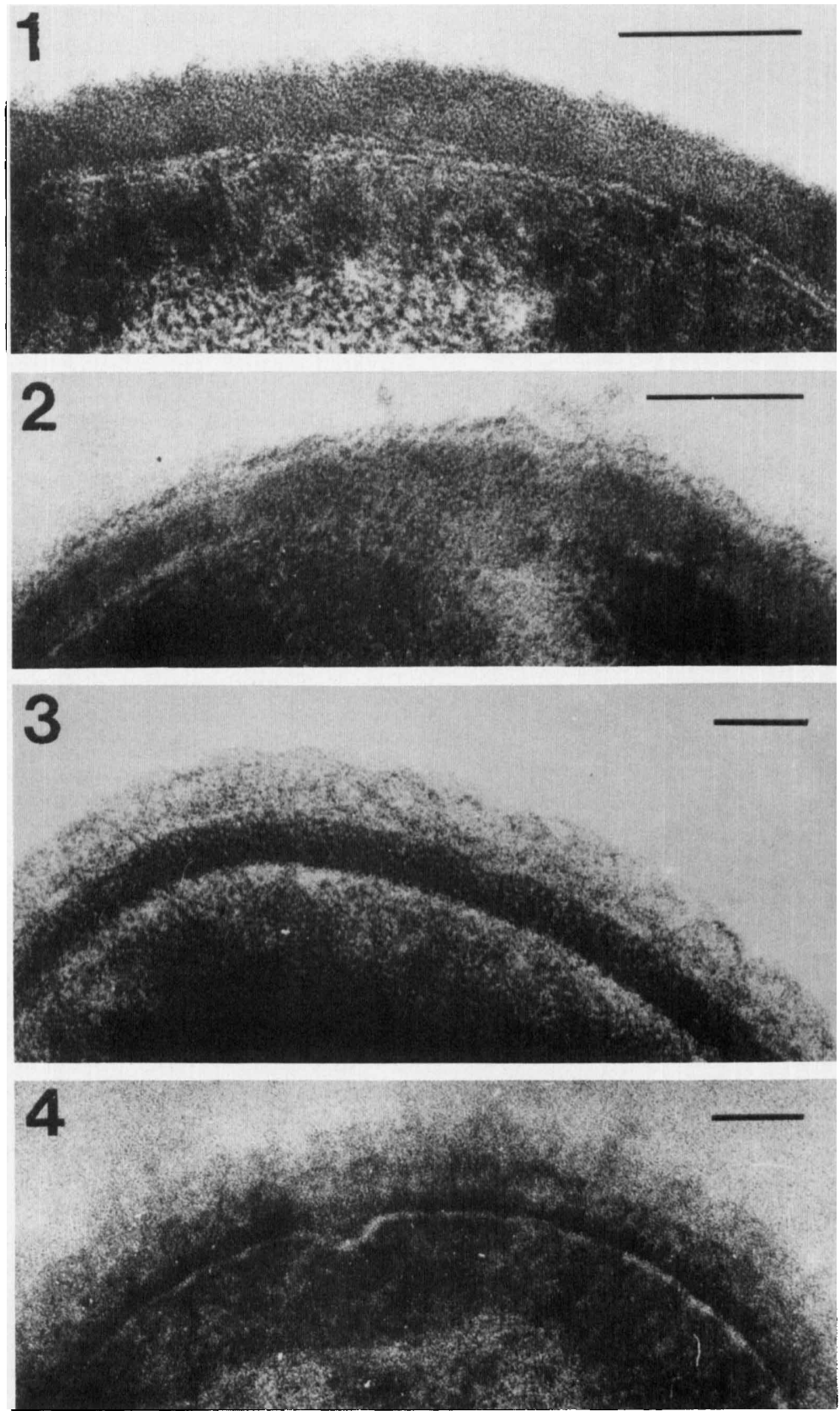

Fig. 1. Section of $\mathrm{M}$. roseus 1057 (fixed with $\mathrm{OsO}_{4}$ ), showing a single homogeneous wall profile. Bars represent 0.1 um on Fig. $1-7$.

Fig. 2. Section of $M$. roseus 1045 (formerly Sarcina erythromyxa) fixed as in Fig. 1, showing an outer layer in addition to the thick, homogeneous, peptidoglycan-containing layer.

FIG. 3. Section of "M. radioproteolyticus" 1056, fixed as in Fig. 1, showing a substantial set of components (at least two) outside of the peptidoglycan-containing layer.

Fig. 4. Section of " $M$. radiophilus" 1055, fixed as in Fig. 1, showing a complex profile like that of " $M$. radioproteolyticus" but with a thinner peptidoglycan-containing layer. 

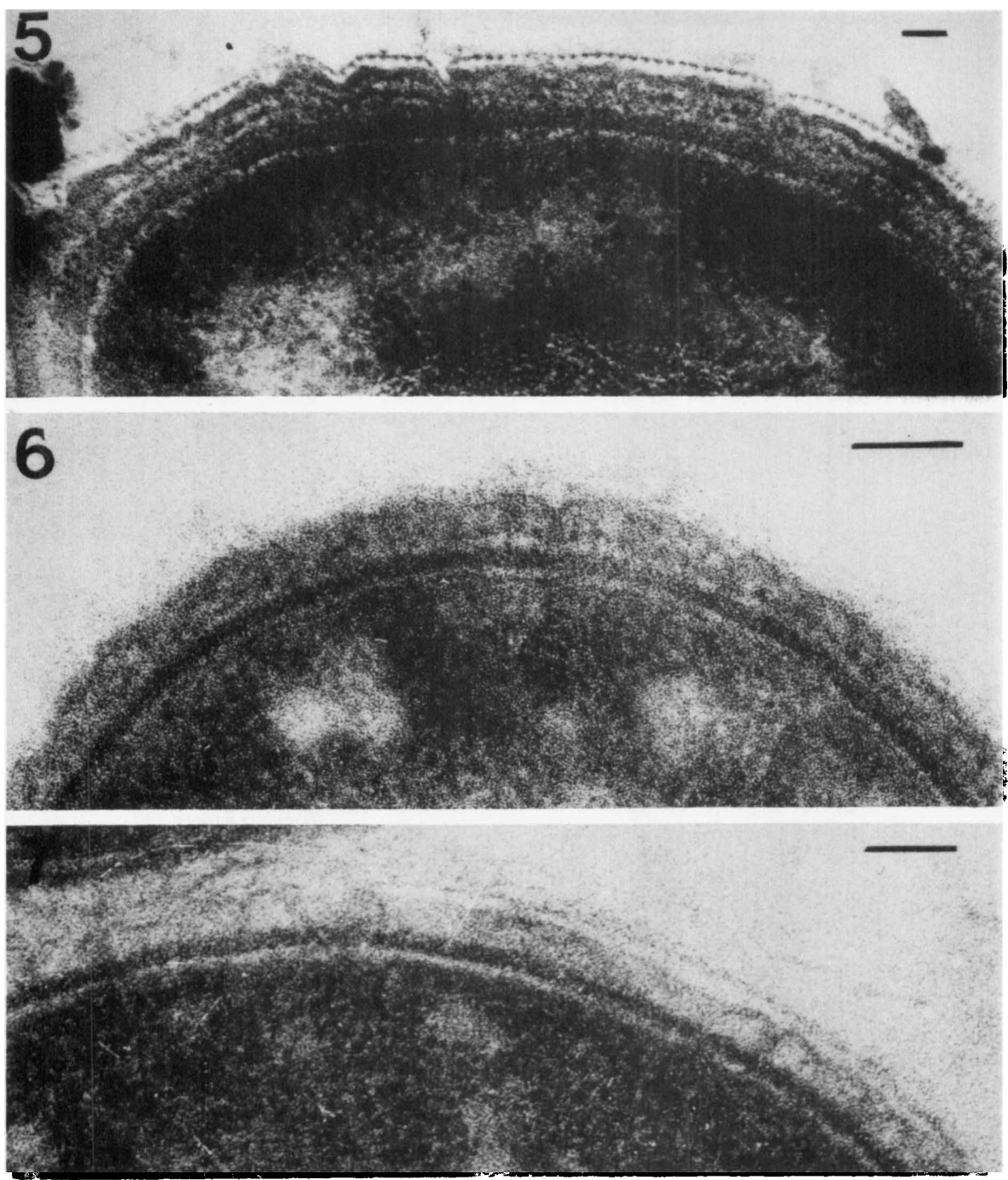

FIG. 5. Section of "M. radiodurans" 298, prefixed with $10 \%$ picric acid before treatment with $\mathrm{OsO}_{4}$ fixative, showing the cell wall profile and at least three layers in addition to the peptidoglycan layer. The latter is fenestrated in other appropriate preparations. The prefixation step provided for a more coherent wall and better adherence of the most superficial protein array.

FIG. 6. Section of $M$. roseus 294 , one of the radiation-resistant fish strains, which was fixed in $\mathrm{OsO}_{4}$. There are at least two superficial layers and, in appropriate preparations, the peptidoglycan layer is fenestrated.

FIG. 7. Section of "M. radiodurans" 1085, one of the miscellaneous strains from Ris $\emptyset$, which was fixed in $\mathrm{OsO}_{4}$. As in Fig. 6., there are at least two superficial layers, and the peptidoglycan layer proved to be fenestrated.

gels; as is evident, there was great diversity. Banding patterns and staining intensities of nonspecific esterase in independent protein extracts of the same strain were reproducible. Some bands were always sharply defined whereas others were diffuse.

Pigment analysis of representative strains. Absorption spectra of the total pigment fraction (in distilled chloroform) extracted from representative strains were determined. In the visible range, the absorption maximum for each strain was as follows: $M$. roseus UWO 1057,485 to $490 \mathrm{~nm}$; $M$. roseus UWO 1039,510 to $520 \mathrm{~nm}$; " $M$. radiodurans" UWO 288,495 to $500 \mathrm{~nm}$; " $M$. radiodurans" UWO 298,485 to $495 \mathrm{~nm}$; “ $M$. radiodurans" 1085 , 490 to $510 \mathrm{~nm}$; " $M$. radi- 


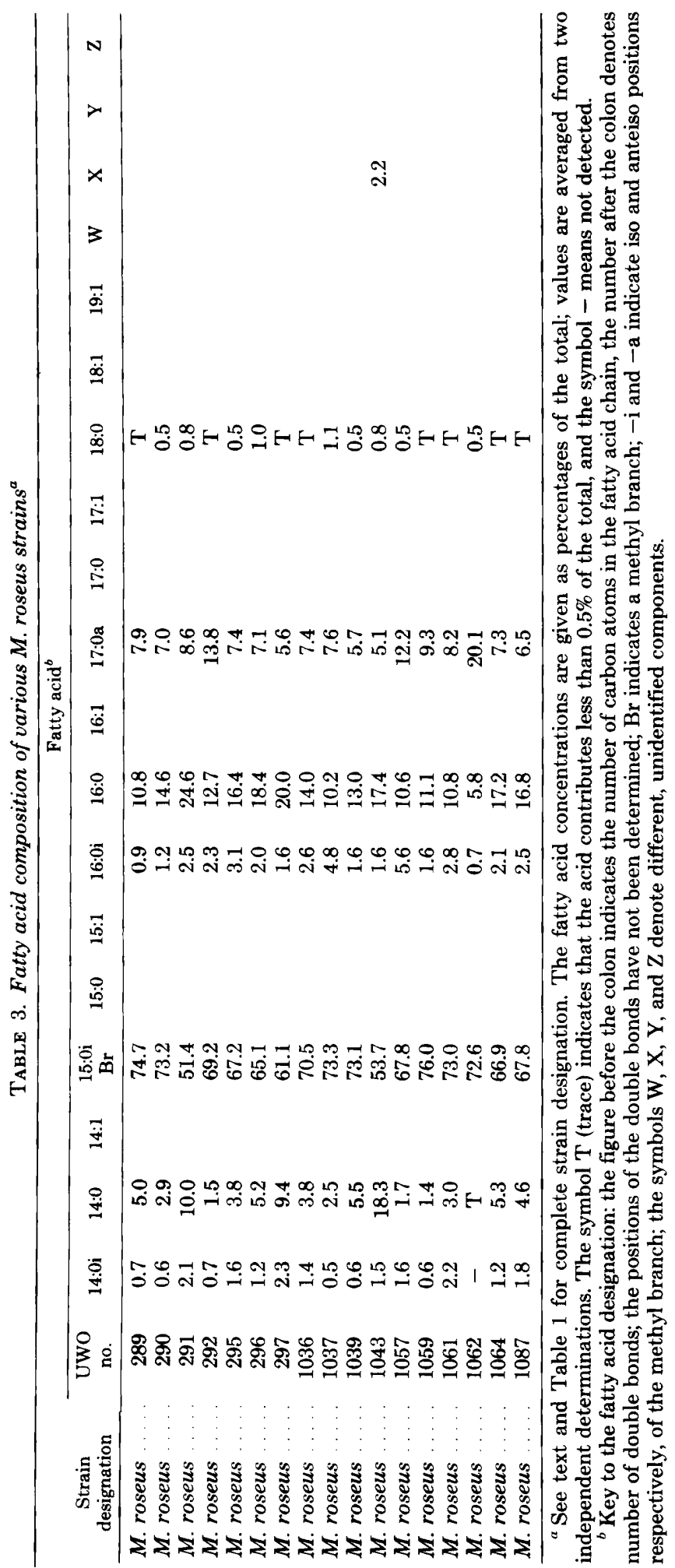




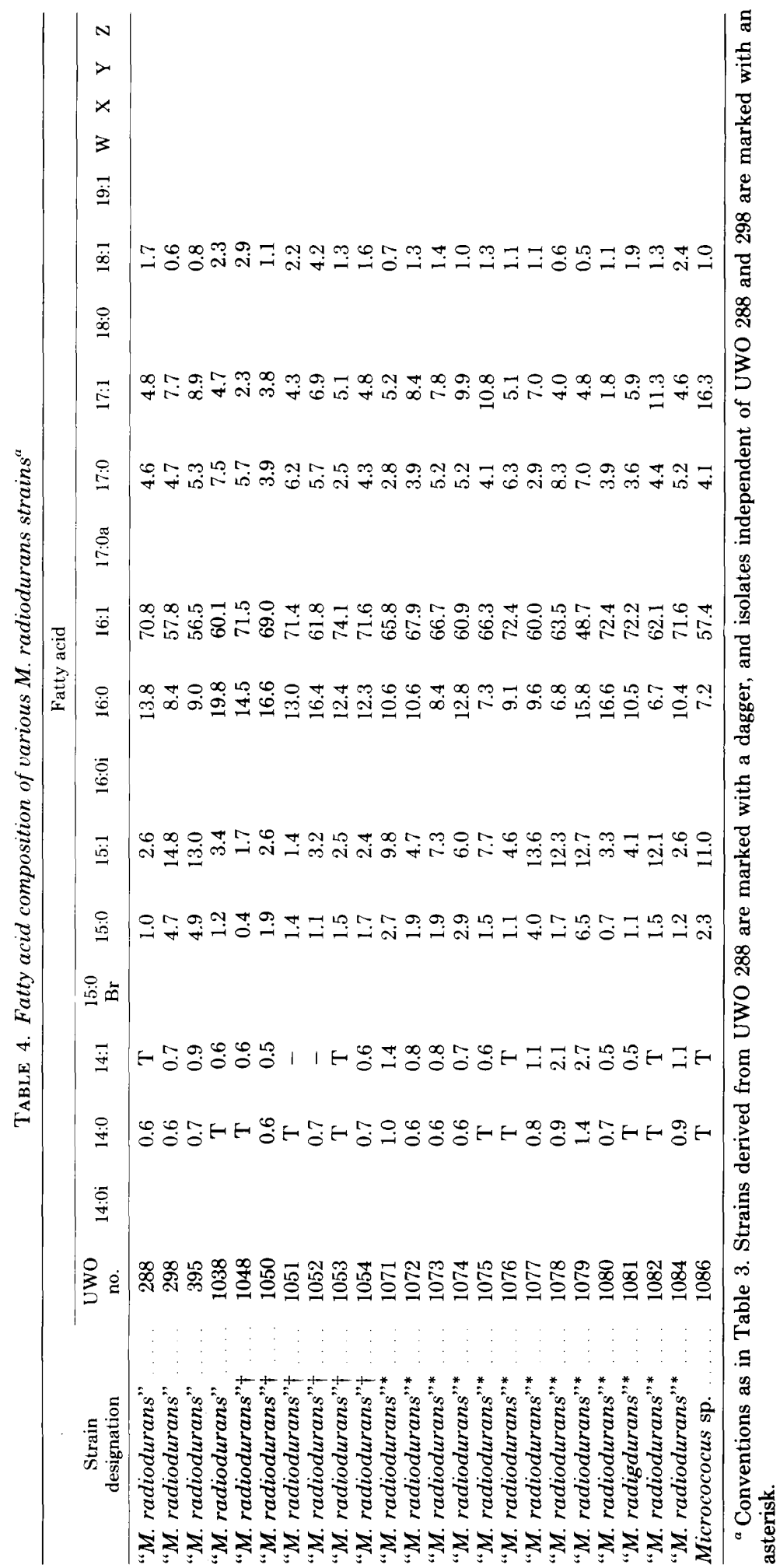




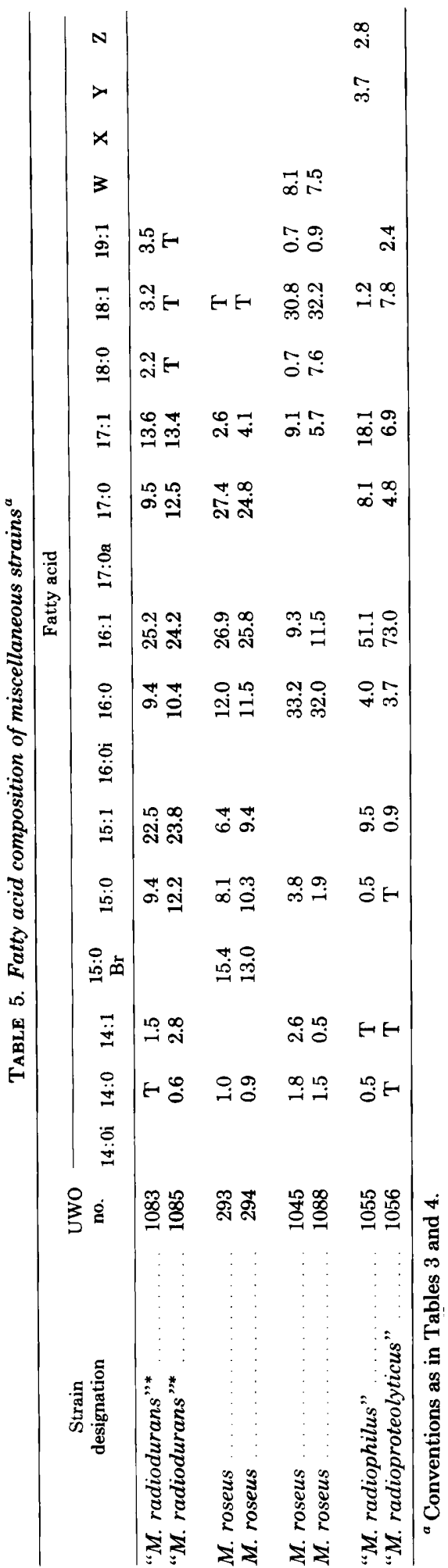

ophilus" UWO 1055, 495 to $500 \mathrm{~nm}$; $M$. roseus UWO 293,490 to $500 \mathrm{~nm}$; and $M$. roseus UWO 1045,450 to $465 \mathrm{~nm}$.

Thin-layer chromatography was used to separate the total pigment fraction into components, not necessarily single pigments, for comparative purposes. Relative mobilities were calculated relative to the fast-migrating $\beta$-carotene front, which was assigned a value of 1 . The number of components detected in each strain and their relative mobilities were as follows: $M$. roseus UWO 1057, four components, $R_{f}$ values $0.17,0.42,0.66$, and $0.80 ; M$. roseus UWO 1039 , one component, $R_{f}$ value 0.87 ; " $M$. radiodurans" UWO 288, five components, $R_{f}$ values 0.17 , $0.36,0.55,0.81$, and 0.89 ; " $M$. radiodurans" UWO 298, six components, $R_{f}$ values $0.07,0.44$, $0.58,0.82,0.89$, and 0.99 ; " $M$. radiodurans" UWO 1083 , four components, $R_{f}$ values 0.38 , $0.60,0.84$, and 0.91 ; " $M$. radiodurans" UWO 1085 , five components, $R_{f}$ values $0.17,0.42,0.60$, 0.83 , and 0.90 ; " $M$. radiophilus" UWO 1055 , one component, $R_{f}$ value $0.90 ; M$. roseus UWO 293, six components, $R_{f}$ values $0.17,0.36,0.57,0.81$, 0.89 , and 0.95 ; $M$. roseus UWO 294 , six components, $R_{f}$ values $0.18,0.36,0.57,0.80,0.89,0.95$; and $M$. roseus UWO 1045, one component, $R_{f}$ value 0.89 .

Peptidoglycan typing of representative strains. There was a clear difference in the diamino acids of the radiation-sensitive and -resistant representative strains. $M$. roseus exhibited the Lys-Ala ${ }_{3-4}$ type, and $M$. agilis, the Lys-Thr-Ala ${ }_{3}$ type. All the radiation-resistant strains were of the Orn-Gly ${ }_{2}$ or ${ }_{2-3}$ type. One exception was found by an incidental testing of one strain outside of the group, $M$. roseus 1088 , which proved to have diaminopimelic acid rather than ornithine.

The molar ratios of the amino acids were consistent with the primary structure proposed for " $M$. radiodurans" by Schleifer and Kandler (41), as follows:

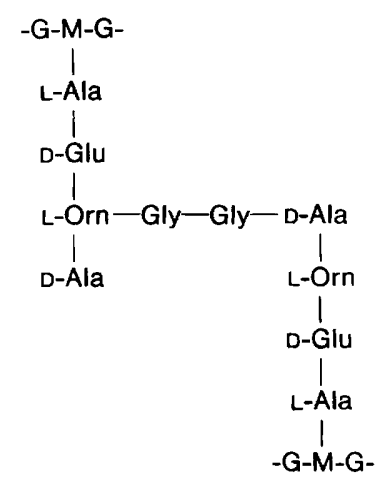



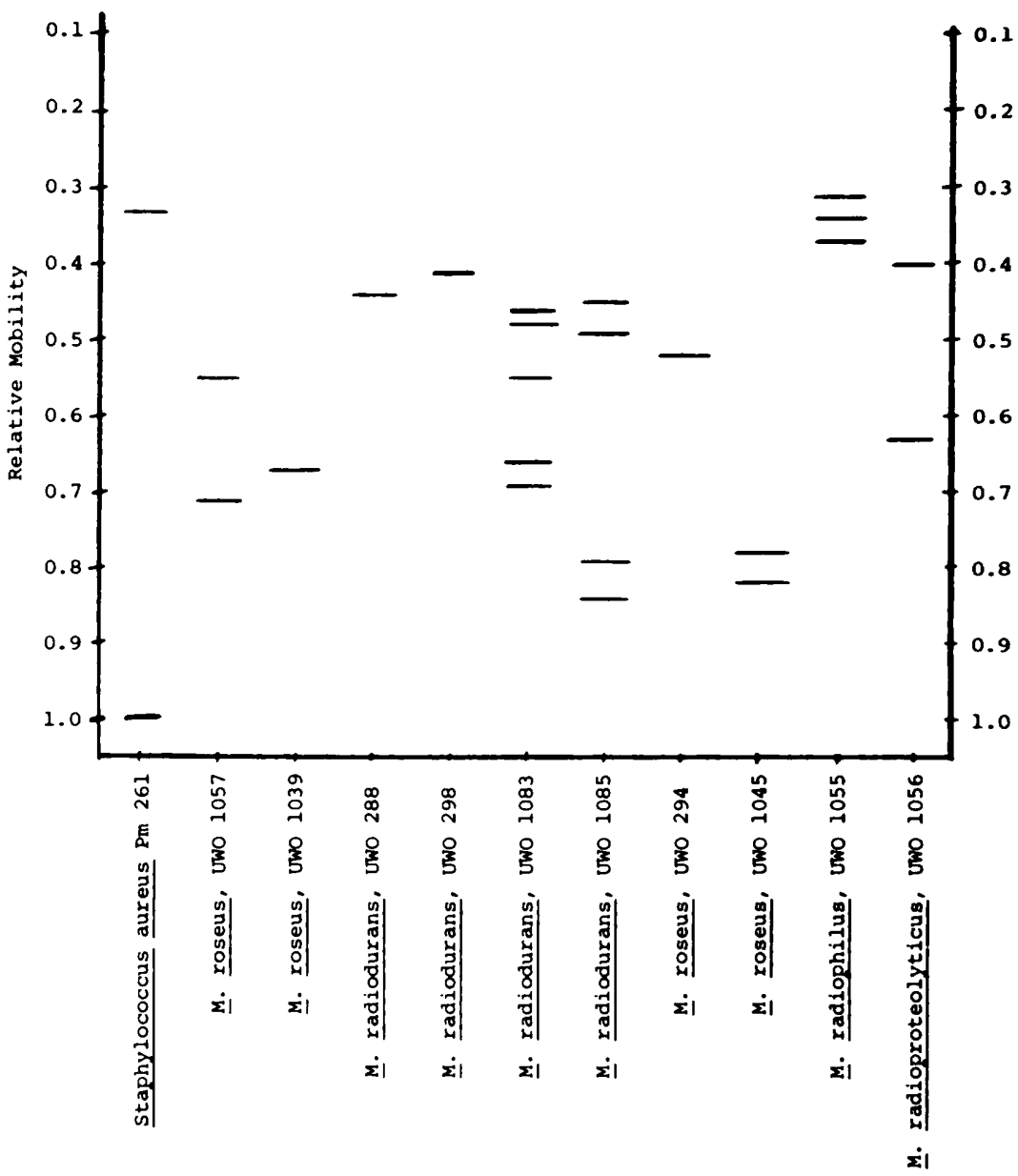

FIG. 8. Schematic zymogram showing relative mobilities of nonspecific esterases of representative strains calculated on the basis of the mobility of the fast-migrating esterase band of Staphylococcus aureus PM 261, which was assigned a value of 1.0 .

DNA base composition and DNA/DNA homology of representative strains. The results of the DNA base composition and DNA/ DNA homology studies are shown in Table 6. The range of $\mathrm{G}+\mathrm{C}$ ratios for veritable $M$. roseus and $M$. agilis strains was 69 to $74 \mathrm{~mol} \%$, whereas groups with $16: 1$ fatty acids and ornithine in the peptidoglycan showed 62 to $71 \mathrm{~mol} \%$. The distinction was more clearly made by the lack of homology $(<21 \%)$ between $M$. roseus 1057 and all the other strains. $M$. agilis 1039 showed insignificant homology to either veritable $M$. roseus, "M. radiodurans," or " $M$. radioproteolyticus" strains or to one of the miscellaneous group, $M$. roseus 294 . There were only two areas of significant homology between strains representing the radiation-resistant grouping as shown by $33 \%$ homology for the Anderson and
Sark strains of " $M$. radiodurans," by the seeming identity of the fish strains ( $M$. roseus 293 and 294 ), and by the $44 \%$ homology of these two strains with the two strains isolated at Ris $\emptyset$ (" $M$. radiodurans" 1083 and 1085). The only exception to the internal consistency of results was the $29 \%$ homology observed between " $M$. radiodurans" 1085 and " $M$. radioproteolyticus" 1056 when the parallel result with " $M$. radiodurans" 1083 gave $5 \%$. The possibility of a mixed culture was proved by showing that about onethird of 50 colonies of strain 1085 as maintained in the laboratory had the phenotype of strain 1056 , an object lesson which reflects on the figure in question and the $\mathrm{G}+\mathrm{C}$ molar ratio for strain 1085.

Comparative cataloging of the $16 S$ ribosomal RNA polynucleotides of selected 
TABLE 6. Mole percent $G+C$ and DNA homology values among red-pigmented Micrococcus strains

\begin{tabular}{|c|c|c|c|c|c|}
\hline \multirow{2}{*}{ Cluster and UWO no. } & \multirow{2}{*}{$\begin{array}{c}\mathrm{G}+\mathrm{C} \\
(\mathrm{mol} \%)\end{array}$} & \multicolumn{4}{|c|}{$\%$ Homology with DNA from strain: } \\
\hline & & 1057 & 298 & 1056 & 294 \\
\hline M. roseus 1057 & 74 & $(100)$ & 1 & 3 & 3 \\
\hline M. agilis 1037 & 69 & 2 & 2 & 0 & 6 \\
\hline M. agilis 1039 & 70 & 8 & 0 & 1 & 1 \\
\hline “M. radiodurans" 298 & 67 & 17 & $(100)$ & 8 & 17 \\
\hline “ $M$. radiodurans" 288 & 67 & 11 & 33 & 6 & 17 \\
\hline " $M$. radioproteolyticus" 1056 & 65 & 17 & 10 & $(100)$ & 8 \\
\hline “M. radiophilus" 1055 & 62 & 5 & 4 & 18 & 4 \\
\hline S. erythromyxa 1045 & 71 & 21 & 1 & 3 & 3 \\
\hline S. erythromyxa 1088(?) & 70 & 9 & 6 & 5 & 5 \\
\hline Miscellaneous (fish) 294 & 69 & 17 & 13 & 6 & $(100)$ \\
\hline Miscellaneous (fish) 293 & 68 & 13 & 12 & 8 & 100 \\
\hline Miscellaneous (Risø) 1083 & 70 & 5 & 10 & 5 & 44 \\
\hline Miscellaneous (Risø) 1085 & $66^{a}$ & 5 & 11 & $29^{a}$ & 44 \\
\hline
\end{tabular}

a These figures are in error; see text.

strains. Oligonucleotide catalogs (Table 7) were developed. From the data base of 6-mers and longer, plus post-transcriptionally modified oligomers and termini, the $\boldsymbol{S}_{A B}$ values were calculated and are shown in Table 8. The $S_{A B}$ values, expressed as a dendrogram (Fig. 9), showed that the three red micrococci formed a cluster quite separate $\left(S_{A B} 0.17\right.$ to 0.29$)$ from the other bacteria, including $M$. roseus and $M$. luteus, which showed an $S_{A B}$ of 0.73 . For comparative purposes we include data for Escherichia coli (51), Bacillus brevis (54), M. luteus (47), and Corynebacterium diphtheriae (B. J. Lewis, Ph.D. thesis, University of Illinois, Urbana, 1977). Any arrangement of the three red micrococci with respect to one another in the dendrogram would be arbitrary and so is expressed as somewhere between the $S_{A B}$ values of 0.51 and 0.63 . The catalogs and dendrogram here provided can be compared to those provided by Stackebrandt and Woese (47) for other Micrococcaceae.

\section{DISCUSSION}

Despite a remarkable superficial phenotypic similarity, it has been possible to determine that " $M$. radiodurans" and organisms like it are distinct from the equally red micrococci, $M$. roseus and $M$. agilis. The distinction is so fundamental, involving genomic and ribosomal sequences as well as the structure of polymeric constituents, that we have to consider these micrococci as being phylogenetically far removed from the Micrococcaceae. However, the tests are esoteric, and practical determinative requirements sug- gest that, even if a new genus were required (B. Brooks and R. G. E. Murray, unpublished data), it would still have to be appended to the Micrococcaceae in Part 14 of Bergey's Manual (3) as a genus of unknown affiliation. Feltham (12) recently published a taxonomic survey of Micrococcaceae (277 strains; 61 characters determined) and concluded, as we have, that $M$. roseus, $M$. agilis, and " $M$. radiodurans" (including the equivalents of our strains UWO 288, 1055 , and 1056) form three distinct clusters deserving of species distinction.

We can justify the alignment of $M$. roseus Flügge 1886 and $M$. agilis (Ali-Cohen 1889) Kocur and Schleifer 1975 (24) with the genus Micrococcus assembled by Baird-Parker (3). They exhibit appropriate wall profiles, peptidoglycan types, branched-chain 15:0 fatty acids, and an appropriate range of $\mathrm{G}+\mathrm{C}$ molar ratios. $M$. ro. seus shows a 0.73 association coefficient in $16 \mathrm{~S}$ ribosomal RNA catalogs to the type species, $M$. luteus (47). Despite this very clear structural and molecular support for the distinction of $\boldsymbol{M}$. agilis and $M$. roseus made by Kocur and Schleifer (24), we anticipate problems in identifying these micrococci using biochemical determinative tests without further standardization of each procedure. For example, our results for these two organisms differ from those of Kocur and Schleifer (24) for glucose oxidation, esculin hydrolysis, and $\beta$-galactosidase ( $o$-nitrophenyl- $\beta$ D-galactopyranoside test) activity. Similarly, Feltham (12) found that nine strains of $M$. roseus produced acid from xylose according to the Analytab Products, Inc., (Plainview, N.Y.) identi- 
TABLE 7. Oligonucleotide catalogs for three red micrococci ${ }^{a}$

\begin{tabular}{|c|c|c|c|}
\hline Sequences & Organisms & Sequences & Organisms \\
\hline 5-mers & & 6-mers-Continued & \\
\hline CCCAG & 3 & UCUUCG & 1 \\
\hline CACCG & $1-3$ & CUUCUG & 1 \\
\hline CAACG & $1-3 ; 1,2$ & UUCAUG & 2 \\
\hline AACCG & 3 & UUACUG & 1 \\
\hline ACACG & $1-3$ & & \\
\hline CAAAG & 3 & UUUUCG & $1-3$ \\
\hline \multirow[t]{2}{*}{ AAAAG } & 3 & UUCUUG & 2 \\
\hline & & UUUAUG & 1,3 \\
\hline UCCCG & $1-3$ & 7-mers & \\
\hline CUCAG & $1-3$ & CAAACCG & 1,2 \\
\hline CACUG & $1-3$ & AACACCG & 2 \\
\hline UACCG & $1-3 ; 3$ & CCAAAAG & 2 \\
\hline ACCUG & $2 ; 2$ & & \\
\hline CUAAG & 1,3 & CCUCACG & 1 \\
\hline UAACG & 3 & CCUACAG & 2 \\
\hline AACUG & 2,3 & CAACICG & $1-3$ \\
\hline ACAUG & $1-3 ; 1$ & CAUACCG & $1-3$ \\
\hline AAUCG & $1-3$ & AUACCCG & $1-3$ \\
\hline AUCAG & 2 & AUCACCG & 2 \\
\hline \multirow[t]{2}{*}{ UAAAG } & $1-3 ; 1-3 ; 2$ & UACAACG & 2 \\
\hline & & UAACACG & 1,3 \\
\hline UCCUG & 1 & AACCUAG & 1 \\
\hline CCUUG & $1-3$ & AUACCAG & $1-3$ \\
\hline UUCAG & $1-3$ & CUAAAAG & 3 \\
\hline UCUAG & $1-3$ & AUAAACG & $1-3$ \\
\hline CUAUG & 2 & CCCUUCG & $1-3$ \\
\hline UCAUG & 1 & CUUCCAG & 1 \\
\hline UAUCG & 3 & UUACCCG & $1-3$ \\
\hline UUAAG & $1-3 ; 3$ & CACUCUG & $1-3$ \\
\hline AAUUG & $1-3$ & ACCUCUG & $1-3$ \\
\hline AUUAG & $1-3$ & CAUUCAG & 1,2 \\
\hline UUCUG & 3 & UAAUACG & $1-3$ \\
\hline UCUUG & $1,2: 1$ & UACAAUG & 3 \\
\hline CUUUG & 2.3 & AUAACUG & 2 \\
\hline AUUUG & 1,3 & CCUUUAG & 3 \\
\hline 6-mers & & UUUACCG & 3 \\
\hline CCACAG & 1 & UAAAUUG & 2 \\
\hline$(\mathrm{CCA}, \mathrm{CA}) \mathrm{G}$ & i3 & 8-mers & \\
\hline CACAAG & $1-3$ & CCCCAAAG & 2 \\
\hline ACAACG & 1 & & \\
\hline ACACAG & 1 & CUCAACCG & 2 \\
\hline AAACCG & 1,3 & CCAACUCG & 2 \\
\hline CCUCAG & 3 & AACCCCUG & 2 \\
\hline ACUCCG & 1,2 & CAAACAUG & 1 \\
\hline CUAACG & $1-3$ & & \\
\hline UCACAG & 2 & CAUCCUCG & 2 \\
\hline UACCAG & 1,2 & CUCAACUG & 3 \\
\hline AAUCAG & 3 & CACUCUAG & 3 \\
\hline \multirow[t]{2}{*}{ AAUACG } & $1-3$ & ACUCCAUG & 3 \\
\hline & & CUAAUACG & 1,2 \\
\hline UUCCCG & $1-3$ & CUACAAUG & $1-3$ \\
\hline UCCUCG & 2 & +CAAACUUG & 3 \\
\hline CCUUCG & 1 & AAUCACUG & $1-3$ \\
\hline CCUAUG & 2 & AAUAACUG & 1 \\
\hline CUACUG & 3 & & \\
\hline CACUUG & 3 & CCCUUAUG & 3 \\
\hline ACCUUG & 3 & UCCUUACG & $1-3$ \\
\hline AUCCUG & $1-3$ & CAUCUUCG & 2 \\
\hline UAAACUG & $1-3$ & AAUUCCUG & 1,2 \\
\hline UAAUCG & 1,$2 ; 1$ & UCUUAAAG & 3 \\
\hline AAUCUG & $1-3$ & CAUUUAAG & 3 \\
\hline AUACUG & 1,2 & CCUUUAUG & 3 \\
\hline \multirow{3}{*}{ UAAUAG } & 1,$3 ; 3$ & AAUUUCUG & 3 \\
\hline & $1-3$ & AUUUAUCG & 1 \\
\hline & & UUUUAAAG & 1,2 \\
\hline
\end{tabular}


TABLE 7-Continued

\begin{tabular}{|c|c|c|c|}
\hline Sequences & Organisms & Sequences & Organisms \\
\hline \multirow{3}{*}{$\begin{array}{l}\text { 9-mers } \\
\quad \text { CCCACCAAG }\end{array}$} & & 11-mers & \\
\hline & 2 & AACCUUACCAG & $1-3$ \\
\hline & & 12-mers & \\
\hline CCUACCAAG & 1 & None & \\
\hline CUCAAACCG & 2 & 13-mers & \\
\hline CUACACACG & $1-3$ & +CUACAAAUCAAAG & 1 \\
\hline \multirow[t]{2}{*}{ UACACACG } & $1-3$ & UCCCACUCCUACG & $1-3$ \\
\hline & & 14-mers & \\
\hline +CCUACCAUG & 3 & +AAACCUAUCCCCAG & 1 \\
\hline CUAACUCCG & $1-3$ & AAUCUUCCCCAAUG & 2 \\
\hline CAACCCUUG & 1,3 & AAUCUUCCACAAUG & 1,3 \\
\hline CUAAUACAG & 3 & 15-mers & \\
\hline \multirow[t]{2}{*}{ AAUAACCUG } & 3 & +UCCACACCCUAAACG & $1-3$ \\
\hline & & 16-mers & \\
\hline \multirow[t]{2}{*}{ UUCCAUCAG } & $1-3$ & +CAACCCCUACCUUCAG & 2 \\
\hline & & Post-transcriptionally & \\
\hline AUAUUUAAG & 1 & modified oligomers & \\
\hline \multirow{2}{*}{$\begin{array}{l}\text { UUUAAUUCG } \\
\text { 10-mers }\end{array}$} & $1-3$ & AAG & $1-3$ \\
\hline & 10-mers & $\mathrm{AAG}$ & $1-3$ \\
\hline CCAUCCCCAG & 2 & AAG & $1-3$ \\
\hline ACCUACCCCG & 3 & GGGC & $1-3$ \\
\hline UCACACCACG & 2 & & $1-3$ \\
\hline ACCUACCCAG & 1 & CCCCG & \\
\hline ACAUCCACAG & 3 & CAACG & $1-3$ \\
\hline +AACACCAAUG & 1,3 & CAAUG & $1-3$ \\
\hline AAACUCAAAG & $1-3$ & NAAUCG & $1-3$ \\
\hline CUCAACCUCG & 1 & UAACAAG & $1-3$ \\
\hline UCACACCAUG & 1,3 & Termini & \\
\hline ACAUCCCAUG & 2 & 5 end: & \\
\hline \multirow{5}{*}{ UAAACCUCUG } & $1-3$ & pUUUUAUG & 1,2 \\
\hline & & (not determined in 3 ) & \\
\hline & & 3 end: & \\
\hline & & AUCACCUCCUUX ${ }_{O H}$ & 1,2 \\
\hline & & AUCACCUCCUUUCU $_{\mathrm{OH}}$ & 3 \\
\hline
\end{tabular}

a Organisms are designated by numbers as follows: 1, "M. radiodurans" UWO-298; 2 , M. roseus UWO-294; 3, " $M$. radiophilus" UWO-1055. Numbers before the semicolon or numbers that stand alone indicate the organisms in which the sequence is present; numbers after the semicolon indicate organisms in which it occurs a second time. Symbols: *, base is modified but precise nature of modification has not been determined; $(+)$, not fully sequenced, other orders possible; $\mathbf{N}$, underlying base is of undetermined character; $\mathrm{X}$, unidentified nucleotide.

TABLE 8. Number of coincident nucleotides and the $S_{\mathrm{AB}}$ values in comparing red micrococci with various reference strains ${ }^{a}$

\begin{tabular}{|c|c|c|c|c|c|c|c|c|}
\hline $\begin{array}{l}\text { Representative } \\
\text { strain }\end{array}$ & 1 & 2 & 3 & 4 & 5 & 6 & 7 & 8 \\
\hline 1. "Micrococcus radiophilus" 1055 & & & 85 & 97 & 11 & 110 & 168 & 140 \\
\hline 2. " $M$. radiodurans" 298 & 0.62 & & & 17 & 32 & 139 & 174 & 138 \\
\hline 3. M. roseus 294 & 0.51 & 0.63 & & & 12 & 122 & 169 & 116 \\
\hline 4. $M$. roseus 1057 & 0.17 & 0.20 & 0.19 & & 11 & 274 & 165 & 154 \\
\hline 5. M. luteus ATCC 23262 & 0.20 & 0.23 & 0.20 & 0 & & 9 & 178 & 148 \\
\hline 6. Corynebacterium diphtheriae ATCC 11913 & 0.20 & 0.24 & 0.22 & 0.49 & 0 & & & 159 \\
\hline 7. Bacillus brevis ATCC 8185 & 0.29 & 0.29 & 0.29 & 0.29 & 0.31 & & & \\
\hline 8. Escherichia coli B-236 & 0.24 & 0.23 & 0.20 & 0.27 & 0.26 & 0.28 & & \\
\hline
\end{tabular}

${ }^{a}$ Data in upper triangle are the total number of nucleotides presented in the coincident oligomers; data in the lower triangle are $\mathrm{S}_{\mathrm{AB}}$ values. 

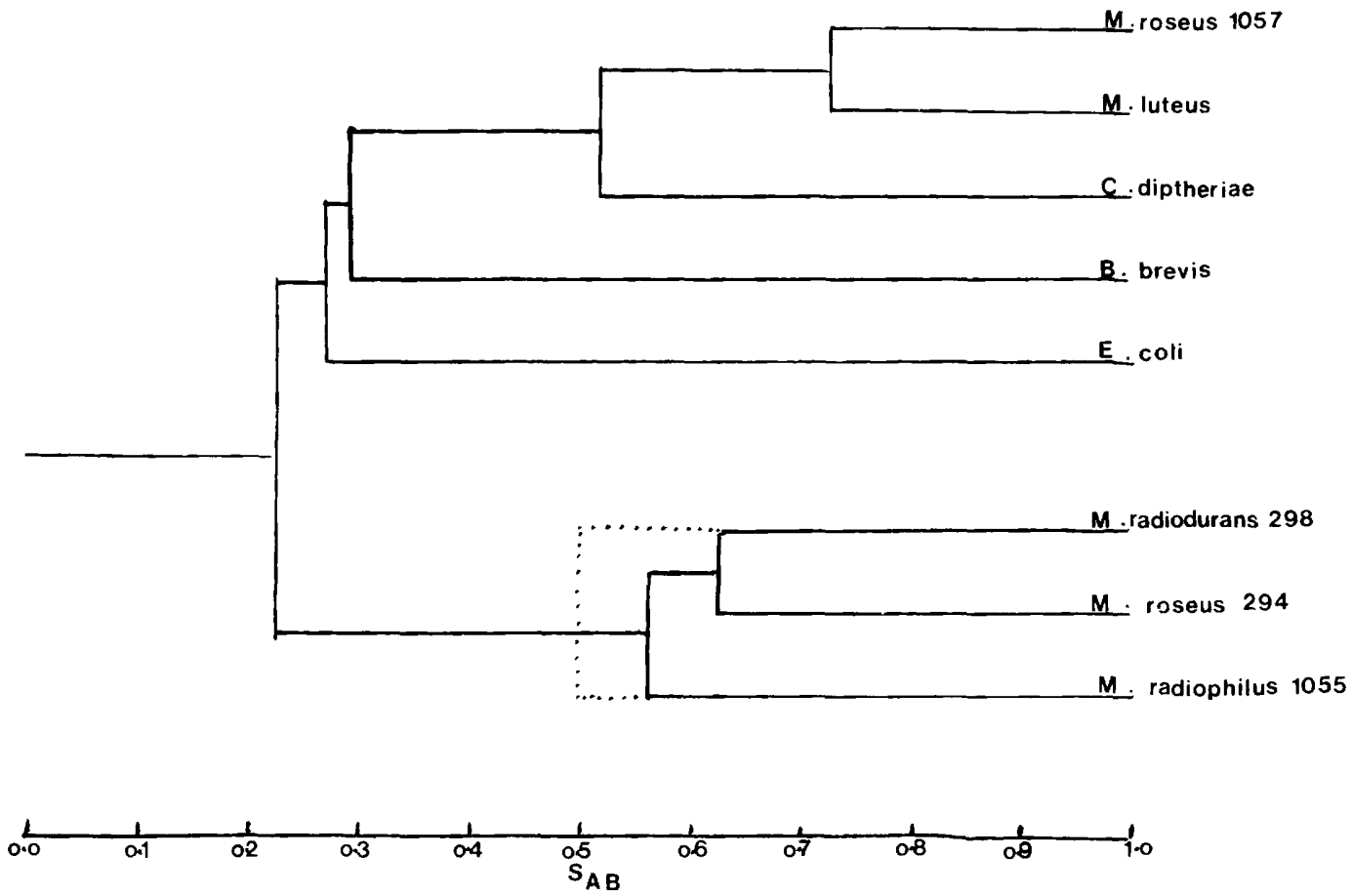

FIG. 9. Dendrogram to show the relationship, in terms of $16 \mathrm{~S}$ ribosomal $R N A$ association coefficients $\left(S_{\mathrm{AB}}\right)$, of " $M$. radiodurans" and like organisms to veritable Micrococcus species and diverse other bacteria. The strains used for comparison were E. coli B236 (51), Bacillius brevis ATCC 8185 (54), M. luteus ATCC 23262 (47), and Corynebacterium diphtheriae ATCC 11913. The relative positions of the three radiation-resistant strains to each other is uncertain and (see Table 8) is in the range of $S_{\mathrm{AB}} 0.5$ to 0.6 , so the range is shown by a dotted line.

fication system ( 5 days at $30^{\circ} \mathrm{C}$ ), which was not the case for our 14 strains. Media and conditions are likely to differ. We record strain variability (summary in Table 9), but differences of this degree are perplexing. Perhaps as simple an addition as 0.5 to $3 \% \mathrm{NaCl}(52)$ might alter results.

We conclude that identifications based on the biochemical tests are similarly hazardous in the " $M$. radiodurans" grouping because four of the seven predominantly negative characters that might be useful for phenotypic distinction from others (Table 2 and summary in Table 9) are not totally reliable. New, positive characters must be sought to aid in identification; some possible approaches such as nonspecific esterases and the carotenoids were not helpful.

Lipid composition provides some useful data for the purposes of bacterial classification, as is apparent in the reviews by Kates (22), Shaw (42), and Lechevalier (26). Although exceptions do exist, these authors indicate that gram-positive bacteria generally have a high proportion of odd-numbered branched-chain (iso and anteiso) saturated or unsaturated fatty acids. Gram-neg- ative bacteria have a high proportion of evennumbered, straight-chain saturated and unsaturated acids and, occasionally, odd-numbered cyclopropane acids. $M$. roseus and its allies in the genus certainly have the gram-positive selection of fatty acids and the group aligned with " $M$. radiodurans" has the selection usually attributed to gram-negative bacteria despite being definitely gram-positive. It is improbable that these organisms have any close relationship to gram-negative bacteria because the Limulus test (56) for endotoxic lipopolysaccharide was negative for the reference strains (S. W. Watson, Woods Hole Oceanographic Institution, Woods Hole, Mass., personal communication).

The lipid peculiarities of this organism are extended by our recent observation (B. G. Thompson, R. Anderson, and R. G. E. Murray, unpublished data) that a form of lipid-containing "outer membrane" lies external to the peptidoglycan of " $M$. radiodurans." Furthermore, the polar lipids are peculiar in character, and there is no trace of the usual phospholipids (phosphatidylcholine, phosphatidylserine, or phosphatidylethanolamine) in an appropriate extract of 
TABLE 9. Phenotypes among 50 strains of red-pigmented micrococci ${ }^{a}$

\begin{tabular}{|c|c|c|c|c|c|c|c|c|}
\hline $\begin{array}{l}\text { No. of } \\
\text { strains }\end{array}$ & $\begin{array}{c}\text { Cluster and } \\
\text { representative } \\
\text { strain }\end{array}$ & $\begin{array}{c}\text { UWO } \\
\text { no. }\end{array}$ & $\begin{array}{l}\text { Growth } \\
\text { in } \\
5 \% \mathrm{NaCl}\end{array}$ & $\begin{array}{l}\text { Growth } \\
\text { at } 37^{\circ} \mathrm{C}\end{array}$ & Nitrate $^{b}$ & $\begin{array}{c}\text { Esculin } \\
\text { hydrolysis }\end{array}$ & Glucose & ONPG \\
\hline 14 & M. roseus & 1057 & + & + & + & $+10 / 14$ & - & - \\
\hline 4 & M. agilis & 1039 & - & - & - & - & - & - \\
\hline 24 & "M. radiodurans" & 288 & $-18 / 24$ & $+23 / 24$ & $-18 / 24$ & - & $-23 / 24$ & - \\
\hline 1 & "M. radiophilus" & 1055 & + & + & - & - & - & - \\
\hline 1 & "M. radioproteolyticus" & 1056 & - & + & - & + & A & - \\
\hline 2 & S. erythromyxa & 1045 & + & + & + & - & - & - \\
\hline 2 & "Haddock" strains & 293 & - & + & + & - & - & + \\
\hline 2 & "Ris $\varnothing "$ strains & 1083 & - & - & + & - & - & + \\
\hline
\end{tabular}

${ }^{a}$ All are gram-positive, catalase-positive, red-pigmented, tetrad-forming micrococci ( 2 to $3 \mu \mathrm{m}$ ). The reactions given are for the representative strains; the fraction of the number of strains giving the reaction is shown when results are inconsistent.

${ }^{b}$ Nitrate reduced to nitrite.

' In peptone-water basal medium.

${ }^{d} o$-Nitrophenyl- $\beta$-D-galactopyranoside test for $\beta$-galactosidase.

whole cells as well as outer membrane. These facts also argue for a unique niche for these organisms in a phylogenetic taxonomy.

Further to the observations of Stackebrandt ant Woese (47), the micrococci aligned with " $M$. radiodurans" are characterized by complex wall profiles, Orn-Gly peptidoglycan types, predominant 16:1 straight-chain fatty acids, and $16 \mathrm{~S}$ ribosomal RNA catalogs dissimilar $\left(S_{A B} 0.23\right)$ tc those of veritable Micrococcus species and a wide range of bacteria. If they separated from mainstream procaryotes at an early stage, one might expect a wide range of these organisms in nature. The diversity of the miscellaneous strains, the low order of intragroup DNA/DNA homology, and the 51 to $63 \%$ association coefficient for the $16 \mathrm{~S}$ ribosomal RNAs of the three members tested suggest that other distinct clones should exist.

The $\mathrm{G}+\mathrm{C}$ molar ratios, DNA homology data, and the $S_{A B}$ values give support to the individuality of "M. radiodurans," " $M$. radiophilus," and " $M$. radioproteolyticus." The high $S_{A B}$ values for these species and a representative of the miscellaneous group provide an argument in favor of association within a single genus in the face of very low DNA hybridization levels. The latter technique, despite an incomplete matrix, provides supportive data for maintaining that strains 288 and 298 are members of the species " $M$. radiodurans" and that strains 293,294 , 1083 , and 1985 should be associated in some as yet unnamed species. The remaining miscellaneous strains may as well be put together with what used to be called S. erythromyxa (UWO 1045). The status of one strain, UWO 1088, remains uncertain because, despite many appropriate characteristics, the peptidoglycan contains diaminopimelic acid and no ornithine. Further studies are needed to settle the matter.

The strains of these extraordinary micrococci are very resistant to radiation $(1,5,16,23,27)$, and this has usually, but not always, been used as a selective factor for isolation. Moseley (32) has shown that radiation resistance is mutable, and, therefore, some relatives may be expected to be found in nature that are not radiation resistant. There is also the observation that " $M$. radiodurans" is unusually resistant to desiccation (11), and this seems to apply to other radiation-resistant bacteria and provides a means for selection that does not involve radiation (39).

It seems premature to attempt some new alignment in the scheme of bacterial classification. Baird-Parker (2) suggested, on more tenuous grounds than ours, that these organisms should be reclassified. At this moment they stand alone, and this isolation is emphasized by the sequence data from ribosomal nucleic acid. It is the opinion of the group concerned with the phylogenetic applications of RNA sequence catalogs (G. E. Fox et al., Science, in press) that " $M$. radiodurans" and its allies form one of eight groups of true bacteria that diverged from some common stem at an early time and that the order of branching is hard to determine. The associations within these groups, based on oligonucleotide sequence, can be surprising; in the case of the Micrococcaceae, for instance, $M$. luteus and $M$. roseus 1057 have strong associations $\left(S_{A B} 0.78\right)$ with Arthrobacter globiformis (47).

Other molecular peculiarities, such as the seemingly unique assortment of polar lipids (Thompson et al., unpublished data), may contribute in the future to defining the level of divergence and possible alignments.

There is one inescapable set of conclusions: " $M$. radiodurans," " $M$. radiophilus," " $M$. radioproteolyticus," and at least two sets of strains in the miscellaneous group (Sarcina erythromyxa and the set clustering around $M$. roseus UWO 294) could be given the status of species. Altogether, they share characters that would allow the circumscription and naming of a new genus. 


\section{ACKNOWLEDGMENTS}

We acknowledge the continuing support of our research by a number of granting agencies, as follows: B. Brooks and R. G. E. Murray, The Medical Research Council of Canada; J. L. Johnson, General Medical Sciences, National Institutes of Health; E. Stackebrandt, Deutsche Forschungsgemeinschaft; G. E. Fox, National Air and Space Administration: and C. R. Woese, National Science Foundation.

We are indebted for cultures and information to $W$. W. Alferow, E. A. Christensen, R. L. Gherna, L. R. Hill, M. Kocur N. F. Lewis, B. E. B. Moseley, B. Österberg, J. F. Spilsbury J. van der Toorn, and M. M. Werner. P. H. A. Sneath and R. K. A. Feltham provided helpful comments. Our colleagues $P$. Lancy, Jr., and R. Anderson assisted in the initiation of some parts of the study. S. W. Watson was kind enough to perform Limulus tests. The technical assistance at the University of Western Ontario of M. Hall, H. Koppenhoefer, and J. Marak is deeply appreciated

\section{REPRINT REQUESTS}

Address reprint requests to: Professor R. G. E. Murray, Department of Microbiology and Immunology, University of Western Ontario, London, Ontario, Canada N6A $5 \mathrm{C} 1$.

\section{LITERATURE CITED}

1. Anderson, A. W., H. C. Nordan, R. F. Cain, G. Parrish, and D. Duggan. 1956. Studies on a radio-resist ant micrococcus. I. The isolation, morphology, cultural characteristics and resistance to gamma radiation. Food Technol. 10:575-577.

2. Baird-Parker, A. C. 1965 . The classification of staphylococci and micrococci from world-wide sources. J. Gen. Microbiol. 38:363-387.

3. Baird-Parker, A. C. 1974. Part 14, Gram-positive cocci, Family I Micrococcaceae, p. 478-489. In R. E. Buchanan and N. E. Gibbons (ed.), Bergey's manual of determinative bacteriology, 8th ed. The Williams \& Wilkins Co., Baltimore.

4. Bligh, E. G., and W. J. Dyer. 1959. A rapid method of total lipid extraction and purification. Can. J. Biochem. Physiol. 37:911-917.

5. Boling, M. E., and J. K. Setlow. 1966. The resistance of Micrococcus radiodurans to ultraviolet radiation. III A repair mechanism. Biochim. Biophys. Acta 123:2633

6. Carroll, K. K. 1961. Quantitative estimation of peak areas in gas-liquid chromatography. Nature (London) 191: $377-378$.

7. Chelm, B. K., and R. B. Hallick. 1976. Changes in the expression of chloroplast genome of Euglena gracilis during chloroplast development. Biochemistry 15:543549 .

8. Crosa, J. H., D. J. Brenner, and S. Falkow. 1973. Use of a single-strand specific nuclease for analysis of bacterial and plasmid deoxyribonucleic acid homo- and heteroduplexes. J. Bacteriol. 115:904-911.

9. Davies, B. H. 1976. Analysis of carotenoid pigments, p 489-532. In T. W. Goodwin (ed.), Chemistry and biochemistry of plant pigments. Academic Press, Inc., New York.

10. Davis, N. S., G. J. Silverman, and E. B. Masurovsky 1963. Radiation resistant, pigmented coccus isolated from haddock tissue. J. Bacteriol. 86:294-298.

11. Dimmick, R. L., and A. B. Akers. 1969. An introduction to experimental aerobiology. Wiley-Interscience, New York.

12. Feltham, R. K. A. 1979. A taxonomic study of the Micrococcaceae. J. Appl. Bacteriol. 47:243-254.

13. Fox, G. E., K. R. Pechman, and C. R. Woese. 1977 Comparative cataloging of $16 \mathrm{~S}$ ribosomal ribonucleic acid: molecular approach to procaryotic systematics.
Int. J. Syst. Bacteriol. 27:44-57.

14. Girard, A. E. 1971. A comparative study of the fatty acids of some micrococci. Can. J. Microbiol. 17:1503-1508.

15. Hill, L. R. 1959. The Adansonian classification of the staphylococci. J. Gen. Microbiol. 20:277-283.

16. Ito, H. 1977. Isolation of Micrococcus radiodurans occurring in radurized sawdust culture media for mushrooms. Agric. Biol. Chem. 41:35-41.

17. Jantzen, E., T. Bergan, and K. Bøvre. 1974. Gas chromatography of bacterial whole cell methanolysates. VI. Fatty acid composition of strains within Micrococcaceae. Acta Pathol. Microbiol. Scand. 82:785-798.

18. Johnson, J. L. 1973. Use of nucleic acid homologies in the taxonomy of bacteria. Int. J. Syst. Bacteriol. 23: 308-315.

19. Johnson, J. L. 1978. Taxonomy of Bacteroides. I. DNA homologies among Bacteroides fragilis and other saccharolytic Bacteroides species. Int. J. Syst. Bacteriol. 28:245-256.

20. Johnson, J. L., and C. S. Cummins. 1972. Cell wall composition and deoxyribonucleic acid similarities among the anaerobic coryneforms, classical proprionibacteria, and strains of Arachnia proprionia. J. Bacteriol. 109:1047-1066.

21. Johnson, J. L., C. F. Phelps, C. S. Cummins, J. London, and F. Gasser. 1980. Taxonomy of the Lactobacillus acidophilus group. Int. J. Syst. Bacteriol. 30:5368.

22. Kates, M. 1964. Bacterial lipids. Adv. Lipid Res. 2:17-90.

23. Kobatake, M., S. Tamabe, and S. Hasegawa. 1973 Nouveau micrococcus radioresistant à pigment rouge, isolé de feces de Lama glama, et son utilisation comme indicateur microbiologique de la radiosterilisation. C.R. Seances Soc. Biol. Paris 167:1506-1510.

24. Kocur, M., and K. H. Sehleifer. 1975. Taxonomic status of Micrococcus agilis Ali-Cohen I889. Int. I. Syst. Bacteriol. 25:294-297.

25. Lancy, P. Jr., and R. G. E. Murray. 1978. The envelope of Micrococcus radiodurans: isolation, purification and preliminary analysis of the wall layers. Can. J. Microbiol. 24:162-176.

26. Lechevalier, M. P. 1977. Lipids in bacterial taxonomyA taxonomists view. Crit. Rev. Microbiol. 5:109-210.

27. Lewis, N. F. 1973. Radio-resistant Micrococcus radi. ophilus sp. nov. isolated from irradiated Bombay duck (Harpodon nehereus). Curr. Sci. 42:504.

28. MacFaddin, J. F. 1976. Biochemical tests for identification of medical bacteria. The Williams \& Wilkins Co., Baltimore.

29. Marmur, J. 1961. A procedure for the isolation of deoxyribonucleic acid from microorganisms. J. Mol. Biol. 3: 208-218.

30. Marmur, J., and P. Doty. 1962. Determination of the base composition of deoxyribonucleic acid from its thermal denaturation temperature. J. Mol. Biol. 5:109-118.

31. Millward, G. R., and D. A. Reaveley. 1974. Electron microscope observations on the cell walls of some gram. positive bacteria. J. Ultrastruct. Res. 46:309-326.

32. Moseley, B. E. B. 1967. The isolation and some properties of radiation-sensitive mutants of Micrococcus radiodurans. J. Gen. Microbiol. 49:293-300.

33. Moseley, B. E. B., and H. J. R. Copland. 1975. Isolation and properties of recombination-deficient mutants of Micrococcus radiodurans. J. Bacteriol. 121:422-428.

34. Moseley, B. E. B., A. Mattingly, and M. Shimmin. 1972. Isolation and some properties of temperaturesensitive mutants of $M$. radiodurans defective in DNA synthesis. J. Gen. Microbiol. 70:399-409.

35. Raj, H. D., F. L. Duryee, A. M. Deeney, C. H. Wang, A. W. Anderson, and P. R. Elliker. 1960. Utilization of carbohydrates and amino acids by Micrococcus ra. diodurans. Can. J. Microbiol. 6:289-298.

36. Reynolds, E. S. 1963 . The use of lead citrate at high pH 
as an electron opaque stain in electron microscopy. $J$. Cell Biol. 17:208-213.

37. Ryter, A., and E. Kellenberger. 1958. Etude au microscope electronique de plasmas contenant de l'acide desoxyribonucléique. I. Les nucleoids des bactèries en croissance active. Z. Naturforsch. Teil B 13:597-605.

38. Sanders, S. W., and R. B. Maxcy. 1979. Patterns of cell division, DNA base compositions, and fine structures of some radiation-resistant vegetative bacteria found in food. Appl. Environ. Microbiol. 37:159-168.

39. Sanders, S. W., and R. B. Maxcy. 1979. Isolation of radiation-resistant bacteria without exposure to radiation. Appl. Environ. Microbiol. 38:436-439.

40. Sanger, F., G. G. Brownlee, and B. G. Barrell. 1965. A two dimensional fractionation procedure for radioactive nucleotides. J. Mol. Biol. 13:373-398.

41. Schleifer, K. H., and O. Kandler. 1972. Peptidoglycan types of bacterial cell walls and their taxonomic implications. Bacteriol. Rev. 36:407-477.

42. Shaw, N. 1974. Lipid composition as a guide to the classification of bacteria. Adv. Appl. Microbiol. 17:63108

43. Skerman, V. B. D., V. McGowan, and P. H. A. Sneath (ed.). 1980. Approved lists of bacterial names. Int. J. Syst. Bacteriol. 30:225-420.

44. Sleytr, U. B., M. Kocur, A. M. Glauert, and M. J. Thornley. 1973. A study by freeze-etching of the fine structure of Micrococcus radiodurans. Arch. Mikrobiol. 94:77-87.

45. Sleytr, U. B., M. T. Silva, M. Kocur, and N. F. Lewis. 1976. The fine structure of Micrococcus radiophilus and Micrococcus radioproteolyticus. Arch. Microbiol. 107:313-320

46. Sneath, P. H. A. 1956. Cultural and biochemical characteristics of the genus Chromobacterium. J. Gen. Microbiol. 15:70-98.

47. Stackebrandt, E., and C. R. Woese. 1979. A phylogenetic dissection of the Family Micrococcaceae. Curr Microbiol. 2:317-322.
48. Subcommittee (ICBN) on Taxonomy of Staphylococci and Micrococci. 1965. Recommendations. Int. Bull. Bacteriol. Nomencl. Taxon. 15:109-110.

49. Tadayon, R. A., K. K. Carroll, and R. G. E. Murray. 1969. Factors affecting the yield and biological activity of lipid extracts of Listeria monocytogenes. Can. J. Microbiol. 15:421-428.

50. Thornley, M. J., R. W. Horne, and A. M. Glauert. 1965. The fine structure of Micrococcus radiodurans. Arch. Mikrobiol. 51:267-289.

51. Uchida, T., L. Bonen, H. W. Schaup, B. J. Lewis, L. Zablen, and $C$. Woese. 1974. The use of ribonuclease $\mathrm{U}_{2}$ in RNA sequence determination. J. Mol. Evol. 3:6377.

52. Welch, A. B., and R. B. Maxcy. 1979. Characteristics of some radiation-resistant hemolytic micrococci isolated from chicken. J. Food Sci. 44:673-675.

53. Woese, C. R., G. E. Fox, L. Zablen, T. Uchida, L. Bonen, K. Pechman, B. J. Lewis, and D. Stahl. 1975. Conservation of primary structure in $16 \mathrm{~S}$ ribosomal RNA. Nature (London) 254:83-86.

54. Woese, C., M. Sogin, D. Stahl, B. J. Lewis, and L. Bonen. 1976. A comparison of the 16S ribosomal RNAs from mesophilic and thermophilic bacilli: Some modifications in the Sanger method for RNA sequencing. J. Mol. Evol. 7:197-213.

55. Work, E., and H. Griffiths. 1968. Morphology and chemistry of cell walls of Micrococcus radiodurans. J. Bacteriol. 95:641-657.

56. Yin, E. T., C. Galanos, S. Krinsky, R. A. Bradshaw, S. Wessler, O. Luderitz, and M. E. Sarmiento. 1972 Picogram-sensitive assay for endotoxin: gelation of $\mathrm{Lim}$. ulus polyphemus blood cell lysate induced by purified lipopolysaccharides and lipid A from gram-negative bacteria. Biochim. Biophys. Acta 261:284-289.

57. Zimmerman, R. J., and W. E. Kloos. 1976. Comparative zone electrophoresis of esterases of Staphylococcus species isolated from mammalian skin. Can. J. Microbiol 22:771-779. 